\title{
Pelaporan Isu Kelapa Sawit dalam Tajuk Akhbar dalam Talian: Analisis Pragmatik
}

\author{
MASLIDA YUSOF \\ NOR HASHIMAH JALALUDDIN \\ HARISHON RADZI \\ KARIM HARUN \\ Universiti Kebangsaan Malaysia
}

\begin{abstract}
ABSTRAK
Dalam tempoh satu dekad, penghasilan minyak sawit oleh Malaysia menghadapi cabaran daripada negara-negara kesatuan Eropah. Mereka menuduh yang penghasilan minyak sawit telah menyebabkan ancaman pada alam sekitar, kepupusan orang utan dan eksploitasi buruh. Sebagai balasan akhbar Malaysia telah banyak menulis bagi menangkas dakwaan ini. Kajian ini bertujuan menganalisis tajuk-tajuk berita mengenai minyak sawit yang digunakan dalam akhbar dalam talian berbahasa Melayu dari perspektif pragmatik. Analisis pragmatik yang difokuskan dalam kajian ini ialah jenis-jenis lakuan tutur yang digunakan sebagai tajuk berita. Berita tentang isu-isu kelapa sawit yang dilaporkan dalam akhbar dalam talian dipilih dari tahun 2017 sehingga 2020. Data diperoleh daripada tiga akhbar dalam talian iaitu Malaysiakini (malaysiakini.com), Berita Harian (bharian.com.my) dan Harian Metro (hmetro.com.my). Sebanyak 70 data tentang isu kelapa sawit telah dikumpulkan secara rawak dan dianalisis menggunakan Taksonomi Lakuan Tutur Searle (1979). Hasil kajian menunjukkan bahawa penulis tajuk berita menggunakan empat jenis lakuan tutur iaitu asertif, direktif, komisif dan ekspresif sebagai cara untuk melaksanakan maksud yang dihajatkan dan menyampaikan mesej kepada pembaca mengenai isu industri sawit Malaysia. Jelasnya, daripada empat jenis lakuan yang digunakan di atas, akuan asertif yang paling kerap digunakan sebagai tajuk berita. Ini memenuhi ciri asertif dalam pelaporan berita atau penyebaran maklumat mengenai minyak sawit kepada pembaca.
\end{abstract}

Kata kunci: Pragmatik, tajuk berita, kelapa sawit, akhbar dalam talian, performatif.

\section{The Reporting on Palm Oil Issues in Online Newspaper Headlines: A Pragmatic Analysis}

\begin{abstract}
Over a decade, the production of palm oil by Malaysia faces challenges from the European Union countries. They accused that the production of palm oil has caused a hazard to the environment, the extinction of orang utan and exploitation of labourers. In return, Malaysian newspapers have written many articles in clearing the accusations. This study aims to analyze the headlines on palm oil used in online Malay newspapers from the perspective of pragmatics. The pragmatic analyses focus on the speech act used in the headlines. The news on palm oil reported in online newspapers is selected from the year 2017 to 2020. Data are obtained from three online newspapers namely Malaysiakini (malaysiakini.com), Berita Harian (bharian.com.my) and Harian Metro (hmetro.com.my). A total of 70 data on palm oil issues are gathered randomly and has been analyzed using Searle Speech Act Taxonomy (1979). The finding shows that the reporters used four types of speech acts that are assertive, directive, commissive and expressive as a tool in achieving the intended meaning and as a source in conveying messages to the audience pertaining to the palm oil issues in Malaysia. It is apparent that from the four types mentioned above, the assertive act is most frequently used in the
\end{abstract}


headlines. It fits the purpose of the assertiveness feature in reporting news or disseminating information on palm oil to the readers.

Keywords: Pragmatics, headlines, palm oil, online newspapers, performative.

\title{
PENGENALAN
}

Pada hari ini, media massa banyak mempengaruhi kehidupan kita. Couldry (2003, dipetik oleh Norhuda, 2016) menjelaskan media ialah gabungan medium komunikasi (radio, muzik, rekod, Internet, televisyen, akhbar, filem dan produk video) atau teks kepada medium lain. Dengan demikian, surat khabar/akhbar terangkum dalam media massa dalam penyampaian maklumat kepada khalayak. Penyampaian maklumat yang merupakan berita merupakan apaapa jenis maklumat baru atau maklumat hal semasa yang disampaikan dalam media massa. Berita ialah peristiwa yang berlaku iaitu bersifat semasa dan ia membawa makna kepada pembacanya. Apa yang penting, berita harus berdasarkan kebenaran dan tidak menyebelahi mana-mana pihak. Dalam konteks kajian, berita yang ditulis ditentukan oleh wartawan yang melaporkan dan kemudian ditentusahkan oleh pengempang maklumat (Norhuda, 2016). Akhbar menanggung tanggungjawab yang besar dari segi penyampaian berita dan kebenaran kepada masyarakat. Wartawan dan editor berperanan membentuk pemikiran, pendapat dan persepsi masyarakat terhadap sesebuah isu sama ada baik atau buruk, betul atau tidak (Shahrul Nazmi \& Ong, 2016). Hal ini dikukuhkan lagi dengan pendapat Abd. Rasyid dan Haidir (2017, hlm. 55). Mereka menyatakan:

\begin{abstract}
A worthy news or news value is what people are anxious to know. It is not only what people want to know, it is also what editors and reporters think is interesting and important. The media, with technical, ideal and pragmatic interests, picked, packed, and eventually distributed news to the audience. The media also position themselves as 'gatekeepers' who decided what issues would be raised on the surface.
\end{abstract}

Selain itu, akhbar merupakan satu saluran yang amat penting dalam menyampaikan peristiwa melalui berita pada kawasan setempat, dalam negara atau di dunia. Pada zaman kini kebanyakan syarikat surat khabar mengalami masalah jualan akhbar mereka kerana wujudnya internet yang mana masyarakat mudah mendapat berita hanya di hujung jari tanpa membeli suratkhabar seperti sebelum ini. Akibat dari itu, banyak syarikat akhbar mengalami kerugian dari segi jualan akhbar dan pengiklanan. Justeru dari itu, syarikat-syarikat akhbar ini perlu berubah dengan drastik dan perlu memayakan akhbar mereka secepat mungkin bagi mengikut perkembangan terkini (Rosman Al-Qadri, 2019). Portal berita dalam talian atau 'media online' merupakan media yang menggunakan internet. Portal berita yang beroperasi sepenuhnya atas talian yang pertama diperkenalkan di Malaysia adalah malaysiakini.com pada tahun 1999. Sambutan dan populariti portal berita berkenaan telah mendorong akhbarakhbar cetak mengambil langkah serupa dengan memperkenalkan versi dalam talian mereka. Begitu juga saluran-saluran media lain seperti televisyen turut memperkenalkan versi dalam talian mereka. Langkah sebegini dilihat sebagai strategi untuk mengekalkan dan menambah jumlah pembaca mereka yang menyedari generasi muda lebih dekat dengan komputer dan Internet (Lee et al., 2016). Walau bagaimanapun, menurut Shahrul Nazmi Sannusi dan Ong (2016), kepentingan akhbar masih tidak boleh diabaikan walaupun kini telah menjadi zaman 
media baharu. Akhbar masih mendapat sambutan daripada golongan orang dewasa dan warga tua.

Reah (1998), yang dipetik dalam Al-Saedi dan Jabber (2020), menyatakan bahawa berita dapat merangkumi maklumat mengenai sesuatu. Berita boleh menjadi tarikan kepada sekumpulan orang atau berita boleh memberi kesan terhadap kehidupan sekumpulan orang ramai. Salah satu tarikan pantas sesuatu laporan berita ialah perhatian kepada tajuk berita (headlines) dalam akhbar. Sesebuah berita yang sempurna bukan sahaja mementingkan kandungan berita dan gambar malahan juga tajuk berita (Shahrul Nazmi \& Ong, 2016). Pembaca tidak akan tertarik atau meneruskan pembacaan mereka tanpa melihat atau mengimbas berita utama atau tajuk berita surat khabar. Pembaca lazimnya, akan membaca tajuk utama berita atau surat khabar jika ingin mengetahui apa yang berlaku di dunia. Ini adalah kerana tajuk berita berperanan untuk menarik perhatian pembaca untuk membaca laporan berita atau surat khabar. Penyunting atau penulis akan mengarahkan pemikiran pembaca supaya memberi fokus kepada isu yang sedang berlaku dan menjadikan isu tersebut penting dalam laporan tersebut. Oleh itu, mereka memanipulasi bahasa dalam tajuk berita dengan menggunakan aspek linguistik dan pragmatik yang berbeza untuk menyampaikan sesuatu isu dalam berita dan surat khabar. Pemilihan bahasa adalah prasyarat untuk memastikan tarikan pembaca terhadap isu-isu tertentu (Al-Hindawi \& Ali, 2018). Penulis membayangkan pendapat dan sikap mereka mengenai isu-isu yang disampaikan dalam berita. Analisis linguistik mengenai cara penyebaran berita ini dapat menunjukkan bagaimana pendapat dan sikap ini disampaikan oleh penyunting atau penulis. Dalam hal ini, analisis pragmatik terhadap tajuk berita dapat mewakili cara yang efektif untuk menunjukkan peranan tajuk berita dalam memulai dan mempertahankan makna yang ingin disampaikan. Menurut Chiluwa (2007, hlm. 70), analisis pragmatik memainkan peranan penting dalam tajuk berita akhbar kerana makna pragmatik adalah berdasarkan kepada niat penulis. Bahasa adalah alat komunikasi dan juga alat untuk menyampaikan kepercayaan, tetapi apa yang lebih penting adalah mengetahui bagaimana bahasa digunakan untuk membentuk idea (Beard, 2000, hlm. 18).

\section{LATAR BELAKANG KELAPA SAWIT DAN PEMBERITAAN}

Dalam makalah ini pengkaji akan memfokuskan kepada isu kelapa sawit yang kerap menjadi tajuk utama akhbar dalam dekad ini. Sawit atau nama saintifiknya Elaeis Guineesis sebenarnya berasal dari Afrika Selatan. Pada tahun 1848, empat anak benih tanaman sawit telah dibawa dari Afrika dan ditanam di Taman Botani Bogor, Indonesia. Pada tahun 1880-an, benih ini kemudiannya telah dibawa ke Deli, Sumatera untuk ditanam sebagai tanaman hiasan. Pada tahun 1911, benih ini kemudiannya dibawa ke Rantau Panjang, Kuala Selangor, juga untuk dijadikan tanaman hiasan. Industri sawit Malaysia bermula pada tahun 1917 apabila Ladang Tenmaran di Kuala Selangor ditanam dengan benih dura Deli dari Rantau Panjang. Apabila pewarisan bentuk buah difahami, penanaman komersil beralih daripada bahan dura kepada kacukan dura x pisifera (D x P). Kacukan D x P menghasilkan buah tenera. Penanaman ladang yang menggunakan bahan D x P berlaku secara mendadak pada awal dekad 1960-an apabila Felda membuka tanah rancangan secara besar-besaran. Penanaman kelapa sawit di Malaysia telah diperkenalkan oleh kerajaan bertujuan untuk membasmi kemiskinan dalam kalangan penduduk luar bandar. Pada tahun 1960-an, Lembaga Kemajuan Tanah Persekutuan (FELDA) telah membuka tanah-tanah baru untuk diteroka dan dijadikan ladang kelapa sawit. Pembangunan dalam industri kelapa sawit amat memberangsangkan dengan penekanan 
diberikan kepada penyelidikan bagi menghasilkan kaedah baru dalam teknologi penanaman, penghasilan benih yang berkualiti dan penghasilan produk-produk baru berasaskan kelapa sawit (usahawan.com, t.th.).

Selain Malaysia, Indonesia telah menjadi pengeluar sawit terbesar di dunia. Pada peringkat awal kelapa sawit ditanam secara kecil-kecilan dan merupakan usaha tanaman keluarga. Di Indonesia, 40\% daripada hasil minyak sawit diperolehi daripada pekebun kecil yang dimiliki oleh keluarga sendiri (Sundaraja et al., 2020). Selari dengan pertambahan penduduk dunia yang bakal mencecah 8.5 billion orang pada 2030, pastinya permintaan terhadap minyak sawit sebagai bahan makanan, kosmetik, biodiesel akan bertambah (Nur Nadia et al., 2020). Natijah dari hasil penanaman kelapa sawit secara besar-besaran oleh Malaysia dan Indonesia, maka lebih banyak hutan tropika yang telah ditebang. Industri minyak sawit negara berhadapan dengan kritikan meluas daripada negara Kesatuan Eropah (EU) dalam beberapa tahun kebelakangan ini. Ini kerana ia dikaitkan penebangan hutan besarbesaran, ketidakseimbangan ekologi dan alam sekitar, pembunuhan orang utan, harimau sumatera dan masalah jerebu. Dalam isu sawit, makalah ini berpendapat bahawa laporan surat khabar tempatan berperanan dalam menghebahkan dan melaporkan isu tentang industri minyak sawit kepada khalayak. Berita dalam akhbar tempatan cenderung untuk menafikan, membalas hujah dan mempertahankan industri ini daripada kritikan dan diskriminasi industri kelapa sawit dari Kesatuan Eropah (EU).

Justeru, kajian ini meneliti aspek pragmatik berdasarkan lakuan tutur dalam penelitian tentang bahasa tajuk-tajuk berita akhbar dalam talian tempatan mengenai isu kelapa/minyak sawit. Penggunaan lakuan tutur adalah sebahagian daripada aktiviti komunikasi manusia. Dengan mengenal pasti jenis-jenis lakuan tutur yang digunakan dapat menjelaskan bagaimana pelaporan tentang isu kelapa sawit ditulis sebagai tajuk berita akhbar dan juga membantu pendengar atau pembaca membuat kesimpulan terhadap sesuatu yang tidak dinyatakan oleh penutur (penyunting dan penulis) secara eksplisit.

Tajuk berita dapat dijelaskan untuk mengetahui fungsinya dalam teks. Menurut Taiwo (2007), tajuk berita penting kerana penggunaannya dapat "memulai, mempertahankan, dan membentuk wacana dari sudut pandangan pembaca". Ungerer (2000) juga menyatakan bahawa tajuk berita adalah terdiri daripada beberapa perkataan yang dapat menunjukkan inti cerita bagi sesuatu berita yang kompleks. Tajuk berita membantu pembaca memahami apa yang ingin disampaikan dalam sesebuah berita (Shahrul Nazmi \& Ong, 2016). Tajuk berita dapat memberikan maklumat yang cepat dan tepat yang membuatkan pembaca ingin mengetahui dengan lebih lanjut apa yang ditulis. Oleh itu, untuk menarik perhatian pembaca, penulis harus mengutarakan tajuk berita yang baik. Secara tidak langsung melalui bahasa, sesuatu kandungan berita akan dirumuskan dalam bentuk tajuk berita yang boleh menarik perhatian pembaca. Kepentingan tajuk berita dalam wacana media digambarkan oleh Bell (1991, hml. 189) yang menyatakan bahawa bahagian yang paling penting adalah jenis bahasa yang digunakan, bagaimana penulis atau penyunting tajuk berita menggunakan bahasa sedemikian rupa sehingga dapat menarik perhatian pembaca dan lakuan tutur apa yang digunakan untuk menyampaikan mesej mereka.

\section{TUJUAN KAJIAN}

Dalam konteks kajian kewartawanan di Malaysia, peranan pemerintah dan akhbar sangat erat. Azlizan dan Norlilawati (2020) menegaskan bahawa akhbar memainkan peranan penting dalam menyampaikan maklumat kerajaan kepada rakyat. Menerusi tulisan yang dipaparkan dalam akhbar dapat dikatakan bahawa akhbar telah menjadi penyampai mesej pemerintah 
kepada khalayak dan menjadi medium untuk mengendurkan ketegangan yang berlaku sebelumnya. Akhbar juga telah menjadi alat bagi mengukuhkan semangat muhibah dan perpaduan di samping menyuntik nilai-nilai kenegaraan melalui berita dan informasi yang dibawakan. Selain itu, segala usaha kerajaan untuk melakukan pembaharuan menerusi dasardasar yang dirancang akan lebih mudah sampai ke sasaran melalui peranan yang dimainkan oleh akhbar. Pendapat ini boleh ditentusahkan dengan kajian bagaimana kerajaan meyakinkan rakyat dengan tindak tanduk mereka termasuk dalam isu pemasaran kelapa sawit yang boleh dikatakan banyak isu konflik sejak akhir-akhir ini.

Kebanyakan kajian yang mengkaji tajuk-tajuk berita memberi fokus kepada sesuatu isu atau peristiwa yang berlaku dalam dalam sesebuah negara. Misalnya isu pilihanraya, politik, peperangan, konflik antara negara dan ekonomi. Sehubungan dengan itu, kajian pragmatik ini memberi fokus kepada tajuk-tajuk berita mengenai isu industri kelapa sawit dengan meneliti lakuan tutur yang digunakan dalam tajuk berita (headlines) surat khabar berbahasa Melayu. Kajian ini juga mendedahkan bagaimana tajuk-tajuk berita akhbar dalam talian berbahasa Melayu melaporkan isu-isu yang berkaitan dengan kelapa sawit dengan menggunakan makna pragmatik untuk membentuk perhatian pembaca dalam penyampaian mesej di sebalik penggunaan tajuk-tajuk berita akhbar. Kajian ini juga akan meneliti kata kerja performatif eksplisit dan implisit dalam lakuan tutur tajuk-tajuk berita akhbar. Kajian ini mengadaptasi lakuan tutur Searle (1979) sebagai teori utama. Kajian ini juga terbatas kepada analisis bentuk dan makna linguistik yang boleh ditemui dalam tajuk berita yang meliputi isuisu kelapa sawit yang datanya dikumpul secara rawak dari tahun 2017 sehingga 2020.

Para penyelidik cuba mencari jawapan untuk soalan berikut:

1. Apakah lakuan tutur yang digunakan dalam tajuk berita akhbar dalam talian dalam melaporkan isu-isu tentang kelapa sawit?

2. Apakah bentuk penyampaian lakuan tutur yang menonjol yang digunakan dalam tajuk berita?

\section{KOSA ILMU}

Kajian-kajian mengenai tajuk berita banyak ditemui dalam kajian di luar negara. Menurut Saedi dan Jabber (2020, tajuk berita akhbar menjadi fokus kepada pelbagai disiplin ilmu yang berbeza. Dalam ilmu linguistik, pelbagai bidang dan aspek linguistik mengenai tajuk berita yang telah dikaji. Dari perspektif sintaksis, Ehineni (2014) telah menganalisis struktur tajuk berita dari segi leksikal dan fungsi kata inti (kepala) dalam tajuk utama akhbar Nigeria. Data kajian ini dikumpulkan dari akhbar nasional Nigeria termasuk 'The Punch', 'The Nation', 'Nigerian Tribune', 'Vanguard' dan 'The Sun'. Kajian ini menggunakan teori sintaksis X-bar iaitu daripada Nahu Generatif untuk menganalisis data. Moncomble (2018) pula meneliti struktur morfosintaktik dalam tajuk-tajuk berita akhbar bahasa Inggeris. Menurut beliau, struktur sintaksis dalam tajuk berita mempamerkan fitur pada tahap permukaan yang tidak bermaksud bahawa tajuk berita di luar konsep piawai linguistik. Moncomble menggunakan korpus daripada pelbagai tajuk berita dalam akhbar The Guardian dan meneliti secara khusus determiner dan verb tenses. Makalah ini menunjukkan bagaimana tajuk berita akhbar bahasa Inggeris membentuk satu piawai tersendiri yang sebenarnya dibina berdasarkan potensi Bahasa Inggeris Standard. Perluasan potensi sintaktik bahasa Inggeris direka bentuk agar sesuai dengan tujuan pragmatik bagi tajuk berita akhbar, iaitu meningkatkan kerelevan artikel surat khabar kepada pembaca. 
Selanjutnya, tajuk berita juga menjadi fokus analisis wacana kritis untuk mengungkapkan ideologi. Taiwo (2007) menyelidiki penggunaan tajuk berita dalam surat khabar Nigeria dan bagaimana tajuk berita ini memainkan peranan untuk membentuk ideologi dan mewujudkan hubungan kuasa. Begitu juga, tajuk berita berperanan dalam retorik. Monsefi dan Mahadi (2017) menggunakan peranti retorik dalam tajuk-tajuk berita Parsi. Tajuk utama Euronews dianalisis menggunakan analisis tekstual retorik untuk meneliti jenis-jenis permainan kata. Kajian mendapati bahawa terdapat pelbagai jenis permainan kata dalam tajuk berita dalam Euronews.

Selain tajuk berita diteliti dari disiplin sintaksis, laras, retorik dan wacana, pragmatik juga berperanan dalam menganalisis tajuk berita. Analisis pragmatik yang menggunakan lakuan tutur dalam tajuk berita telah dikaji oleh sebilangan penyelidik. Antaranya, Al-Saedi dan Jabber (2020) mengkaji aspek pragmatik yang digunakan dalam wacana media terutamanya tajuk berita surat khabar rasmi Iraq (Alsabah Newspaper) dengan tumpuan kepada peristiwa yang berlaku di Iraq dari Mac hingga Disember 2017 yang merangkumi konflik Iraq - ISIS. Beliau menggunakan Taksonomi lakuan tutur Searle (1979). Hasil kajian menunjukkan bahawa penulis tajuk berita menggunakan semua lakuan tutur sebagai strategi untuk menyampaikan makna yang dihajati. Di samping itu, penemuannya juga mendedahkan bahawa ekspresif dan deklaratif adalah lakuan tutur yang paling menonjol digunakan dalam sampel tajuk berita. Penggunaan lakuan tutur ini dalam tajuk berita akhbar Alsabah menggambarkan perasaan pembaca untuk menzahirkan perasaan kejayaan dan pembebasan.

Kajian oleh Al-Hindawi dan Ali (2018) juga meneliti jenis lakuan tutur yang digunakan dalam tajuk berita CNN dan BBC mengenai konflik di Syria. Lima puluh enam tajuk berita dipilih di setiap saluran berita ini iaitu 26 daripada CNN dan 30 daripada BBC dari September 2015 hingga Mei 2016. Penyelidikan yang dilakukan dalam kajian ini menunjukkan bahawa lakuan tutur yang digunakan dalam tajuk berita di saluran berita boleh menjadi cara yang baik untuk memahami maksud yang hendak disampaikan oleh penulis. Lakuan tutur asertif didapati paling kerap digunakan dalam tajuk berita di saluran berita CNN dan BBC. Dalam kedua-dua saluran didapati juga, tajuk berita saluran berita CNN menggunakan lakuan tutur komisif yang lebih kerap berbanding saluran berita BBC yang menunjukkan kekerapan yang tinggi bagi penggunaan lakuan tutur ekspresif.

Rabiah et al. (2019) dalam artikelnya Identification and Analysis of Commissive Speech Acts to Decode Indirect Messages in News Headlines membincangkan mesej tidak langsung dalam tajuk berita CNN yang ditulis mengenai pelbagai isu politik, urusan diplomatik dan keselamatan di Pakistan. Kajian ini juga mengkaji peranan linguistik dan juga elemen kontekstual dalam mengenal pasti mesej tidak langsung dalam tajuk berita dalam bentuk lakuan tutur. Kajian ini mendapati, tajuk berita mempunyai makna yang dienkodkan secara pragmatik. Tajuk berita bukan sekadar mengandungi maklumat, tetapi juga dikaitkan dengan penyampaian pelbagai mesej yang berkaitan dengan komitmen tindakan pada masa hadapan, kemungkinan tindakan masa depan, mengumumkan tindakan pada masa hadapan, menyatakan niat penutur mengenai aktiviti masa hadapan dan janji untuk masa hadapan. Peranti linguistik dan konteks yang berkaitan dengan tajuk berita memainkan peranan penting dalam pengenalpastian dan analisis mesej tidak langsung pada tajuk berita.

Qomariyah (2019) menganalisis jenis lakuan tutur yang digunakan pada tajuk utama Jakarta Post dan Jakarta Globe selepas Pilihan Raya Umum Indonesia 2019. Terdapat 70 tajuk berita yang dipilih dari dua laman web dalam talian yang terdiri daripada 20 tajuk berita daripada dunia Jakarta Globe News dan 50 tajuk berita daripada Jakarta Post. Statistik 
deskriptif digunakan. Kajian ini mendapati, lakuan tutur asertif merupakan pilihan tertinggi daripada jenis lakuan tutur yang lain yang digunakan dalam laman web Jakarta Globe dan Jakarta Post. Selain itu, tajuk berita yang digunakan dalam Jakarta Post dan Jakarta Globe setelah pilihan raya umum Indonesia menunjukkan kedua-duanya sama dari segi peratusan penggunaan asertif dan deklaratif sebagai tajuk berita. Kajian penggunaan jenis-jenis lakuan tutur dalam tajuk berita merupakan satu cara untuk mengungkap makna tersirat yang dapat mempengaruhi pembaca terhadap isu-isu tertentu dan juga boleh mempengaruhi kepercayaan pembaca.

Dalam konteks bahasa, terdapat kajian tempatan yang mengkaji aspek penggunaan dan kesalahan bahasa dalam akbar. Antaranya ialah kajian yang diselidiki oleh Mohd Hazreen dan Sharil Nizam (2019), serta Mohd Hazreen, Sharil Nizam dan Nor Azuwan Yaakob (2019). Selain daripada jenis pertuturan dan lakuan bahasa yang dikaji di atas, salah satu aspek yang boleh diambil kira adalah teknik pemberitaan itu sendiri.

Menurut Azahar dan Adibah Ismail (2018), bagi memastikan agenda kerajaan dalam menyampaikan berita berjaya, para wartawan menggunakan teknik berita berstrategik (strategic news). Selalunya berita berstrategik ini adalah mengenai dasar dan perancangan kerajaan dalam memastikan polisi dan tindak tanduk mereka dalam menangani isu negara seperti kelapa sawit memberi faedah kepada rakyat dan kerajaan sendiri.

Namun pada masa yang sama, dalam dunia pemberitaan, ada juga teknik memerangkap atau 'framing' boleh dilakukan. Ini selaras dengan pendapat Osama, Mohamed Oklah dan Mohd Faizal (2020, hlm. 4). Mereka menyatakan:

In communication, framing defines the way news media coverage shapes mass opinion by using these specific frameworks to help guide their audience to understanding Frames lead audiences to accept one meaning over another. Media frames provide boundaries around a news story and determine what is and is not newsworthy or notable. A frame also refers to the way media as gatekeepers organise and present the ideas, events, and topics they cover.

Berdasarkan sorotan kajian lepas, kurang ditemui kajian-kajian yang menyentuh mengenai tajuk-tajuk berita akhbar dalam kalangan pengkaji bahasa tempatan. Sehubungan itu, kajian ini akan mengisi kelompangan kajian sebelum ini iaitu menyelidiki aspek pragmatik dalam tajuk berita di akhbar dalam talian dengan tumpuan kepada berita kelapa sawit. Dengan kata lain, kajian ini memfokuskan pada penerapan klasifikasi taksonomi tindakan Searle (1979) pada tajuk-tajuk berita akhbar.

\section{METODOLOGI}

Perkembangan teknologi, khususnya berkaitan dengan media memberikan impak yang cukup besar dalam industri penerbitan akhbar di negara ini (Shahrul Nazmi \& Normah, 2015). Dahulu, masyarakat mampu mendapatkan informasi dan berita hanya daripada surat khabar yang bercetak sahaja. Ekoran dengan perkembangan teknologi pada masa kini, informasi dan berita kini, boleh dicapai dengan mudah, pantas dan di mana-mana sahaja dengan adanya talian internet. Hal ini jelas menunjukkan bahawa kewujudan internet telah memberi perubahan yang sangat drastik dalam penerbitan akhbar terutamanya berita dalam talian yang semakin menjadi pilihan untuk pengguna. Berita dalam talian merujuk kepada akhbar cetak edisi dalam talian yang boleh diakses menggunakan internet. Satu kelebihan dengan 
edisi akhbar dalam talian adalah keupayaan untuk mengambil bahagian dalam pelbagai pemilihan pendapat dan balasan dan komen yang mengambil masa dalam kes edisi cetak (The Birth Site, 2020).

Data dikumpulkan daripada tajuk-tajuk berita akhbar-akhbar tempatan berbahasa Melayu yang diterbitkan secara dalam talian pada tahun 2017 sehingga 2020. Tiga akhbar dalam talian yang dijadikan sumber data ialah Malaysiakini (malaysiakini.com) Organic Traffic $=2,165,695 /$ sebulan, Berita Harian (bharian.com.my) Organic Traffic $=1,242,536 /$ sebulan dan Harian Metro (hmetro.com.my) Organic Traffic $=1,207,104 /$ sebulan. Pemilihan tiga akhbar bahasa Melayu adalah berdasarkan laporan dari Rosman Al-Qadri (2019) yang telah menyenaraikan 10 berita di akbar dalam talian yang mempunyai "Organic Traffic" yang tinggi pada 20 Mei 2019 dalam laman web mereka. Lee et al. (2016) juga menjelaskan tiga akhbar cetak yang mempunyai khalayak terbesar adalah Berita Harian Online $(2,509,828)$, Harian Metro Online $(2,112,431)$, dan Sinar Harian $(1,725,385)$. Manakala akhbar online pula adalah malaysiakini (versi Bahasa Melayu) iaitu seramai 918,261 diikuti malaysiakini (versi Bahasa Inggeris) dan Oriental Daily News 東方日報 $(596,762)$.

Tajuk berita yang diberi tumpuan ialah berita mengenai industri kelapa sawit. Industri minyak sawit negara berhadapan dengan kritikan meluas dalam beberapa tahun kebelakangan ini kerana ia dikaitkan dengan penebangan hutan dan sering kali dituduh menjadi punca jerebu (https://www.bharian.com.my/berita/nasional/2019/03). Artikel ini akan meneliti pelaporan akhbar dalam talian berkenaan kelapa sawit dari sudut penginterpretasian makna, iaitu pragmatik. Apakah jenis lakuan bahasa yang ditonjolkan oleh penulis dalam menyampaikan berita tentang kelapa sawit dalam akhbar-akhbar ini. Sebanyak 70 sampel tajuk berita tentang kelapa sawit telah dikumpulkan secara rawak daripada tiga akhbar dalam talian iaitu malaysiakini.com, bharian.com.my dan hmetro.com.my yang meliputi tahun 2017 sehingga 2020. Data akan dianalisis berdasarkan klasifikasi Searle mengenai lakuan tutur. Data dianalisis dengan menggunakan kualitatif (pragmatik) dan kuantitatif yang berasaskan deskriptif statistik. Sebelum menganalisis data, data tersebut dikategorikan berdasarkan lakuan tutur yang digunakan dalam tajuk berita dan kekerapan dikira dengan menggunakan peratusan bagi setiap kategori.

\section{KLASIFIKASI LAKUAN TUTUR SEARLE (1979)}

Teori lakuan tutur, idea asasnya dibentuk oleh ahli falsafah Oxford pada akhir tahun 1930, dan dibentangkan dalam kuliah beliau di Oxford pada 1952-1954, selepas itu disampaikan dalam siri kuliah Wiliam James yang dibentangkannya di Harvard pada tahun 1955. Idea ini kemudiannya dibukukan, dengan judul How to Do Things with Words (1962). Setelah kematian Austin pada tahun 1960, ideanya telah diperhalus, disusun serta dikembangkan oleh pelajarnya di Oxford, iaitu ahli falsafah Amerika, John R. Searle $(1969,1979)$. Menurut Austin, bahasa tidak hanya digunakan untuk menerangkan tentang dunia, tetapi ujaran juga boleh digunakan untuk melakukan sesuatu, yang disebut oleh Austin sebagai tindakan performatif dan membezakannya daripada membuat penegasan atau menyatakan yang dipanggil sebagai konstatif. Austin (1962) menyatakan bahawa perfomatif boleh bersifat eksplisit atau implisit. Performatif eksplisit mengandungi kata kerja performatif yang menjadikan makna kata kerja itu tersurat. Sebaliknya, performatif implisit adalah ujaran yang diujarkan tanpa kata kerja performatif iaitu makna tindakan illokusi boleh disampaikan secara tersirat. Contoh berikut menjelaskan perbezaan antara performatif eksplisit dengan performatif implisit. 
a. Saya berjanji akan datang esok.

b. Saya akan datang esok.

Dalam teori ini juga, Austin (1962) menjelaskan setiap peristiwa pertuturan (atau lakuan tuturan) mempunyai sekurang-kurangnya tiga aspek iaitu: lakuan lokusi (iaitu penghasilan ekspresi linguistik yang bermakna) lakuan illokusi (iaitu lakuan yang dihajati untuk ditunjukkan oleh penutur ketika dia mengujarkan ekspresi linguistik itu, disebabkan oleh kelaziman atau amalan yang dikaitkan dengannya sama ada secara eksplisit atau implisit). Seterusnya, lakuan perlokusi iaitu kesan atau akibat kepada pendengar semasa pengujaran ekspresi linguistik itu). Ketiga-tiga lakuan ini berlaku serentak apabila menyatakan sesuatu.

Kajian ini menggunakan gagasan lakuan tutur Searle (1979) iaitu versi yang lebih terkini berbanding versi 1969. Menurut taksonomi Searle (1979), lakuan tutur dikelompokkan kepada lima jenis iaitu asertif, direktif, komisif, ekspresif dan deklaratif. Lakuan tutur representatif atau asertif merupakan jenis perlakuan tutur bahasa yang mengikat penutur kepada kebenaran proposisi yang diungkapkan, dan lakuan ini membawa nilai-benar terhadap ungkapan tersebut. Lakuan ini juga, mengungkapkan kepercayaan penutur dan mengakibatkan penutur bertanggungjawab terhadap kebenaran ujaran yang dilafazkannya (Searle, 1979). Justeru, ujaran sedemikian menghendaki penutur mengatakan yang benar dan tidak mengujarkan sesuatu yang palsu atau berbohong. Antara fungsi asertif antaranya ialah menyatakan, mendapatkan maklumat, menafikan, menyarankan, melaporkan dan mengandaikan.

Direktif merupakan jenis perlakuan tuturan bahasa yang menggambarkan usaha oleh penutur untuk membuatkan pendengar melakukan sesuatu. Perlakuan tuturan bahasa ini melahirkan keinginan penutur supaya pendengar membuat sesuatu (Searle (1979, hlm. 11). Justeru, kuasa ujaran direktif menghasilkan kesan tertentu yang dapat dilihat melalui tindakan dan respons yang ditunjukkan oleh pendengar. Ekspresif merupakan perlakuan tuturan bahasa yang menunjukkan sikap psikologi atau mood penutur seperti bahagia, duka, dan suka/ tidak suka Searle (1979). Dengan kata lain, ujaran yang mengandungi fungsi ini menunjukkan dan mendedahkan perasaan dan sikap penutur terhadap pendengar.

Komisif merupakan jenis perlakuan tuturan bahasa yang mengikat penutur kepada sesuatu tindakan pada masa akan datang. Perlakuan tuturan bahasa ini melahirkan niat penutur untuk melakukan sesuatu Searle (1979). Lakuan ini, menyebabkan penutur melakukan sesuatu tindakan dan perbuatan pada masa muka. Lakuan bahasa deklaratif atau penyata merupakan perlakuan tuturan bahasa yang memberikan perubahan segera dalam sesuatu keadaan semasa (Searle, 1979). Oleh sebab perlakuan tuturan bahasa ini bergantung pada institusi ekstralinguistik bagi kejayaan pelaksanaannya, ia juga boleh dinamakan perfomatif institusi. Dalam melaksanakan perlakuan tuturan jenis ini, penutur membawa perubahan kepada dunia, iaitu penutur memberi keselarian antara kandungan proposisi dengan dunia.

Dalam makalah ini, lakuan tutur menjadi unit analisis. Untuk tujuan ini, teori lakuan tutur Searle (1979) diaplikasi. Tajuk berita diklasifikasi berdasarkan jenis-jenis asas lakuan illokusi iaitu representatif, komisif, direktif dan deklaratif. 


\section{ANALISIS}

Dengan memberi tumpuan kepada tajuk berita kelapa sawit dalam tiga akhbar atas talian, sebanyak 70 sampel secara rawak telah dikumpulkan. Daripada 70 sampel tajuk berita, 20 tajuk berita daripada malaysiakini.com, 30 tajuk berita daripada bharian.com.my dan 20 sampel daripada hmetro.com.my. Analisis kuantitatif kajian menunjukkan bahawa tajuk berita dapat melaksanakan lakuan tutur dan ianya dapat diklasifikasikan mengikut kategori Taksonomi Searle pada (1979). Berdasarkan klasifikasi lakuan tutur Searle (1979), didapati hanya empat jenis lakuan tutur yang digunakan oleh penulis sebagai tajuk berita iaitu lakuan tutur asertif atau representatif, lakuan tutur direktif, lakuan tutur komisif dan lakuan tutur ekspresif. Daripada empat jenis lakuan tutur ini, didapati lakuan tutur asertif paling kerap digunakan sebagai tajuk berita manakala lakuan tutur ekspresif paling sedikit dijadikan tajuk berita. Dapatan kajian ini menyamai kajian Al-Hindawi dan Ali (2018) serta Qomariyah (2019) yang menunjukkan lakuan tutur asertif paling kerap digunakan sebagai tajuk berita. Dalam Jadual 1 di bawah, ditunjukkan kekerapan dan peratusan bagi penggunaan tajuk berita dalam data kajian. Kekerapan dan peratusan penggunaan lakuan tutur asertif sebagai tajuk berita adalah 52 atau 74\%, lakuan bahasa direktif menunjukkan 9 kekerapan iaitu 13\%, 2 kekerapan lakuan tutur ekspresif iaitu 3\% dan 9\% atau 6 kekerapan bagi penggunaan lakuan tutur komisif. Kajian ini juga menemui 1 atau 1\% tajuk berita yang menggabungkan dua lakuan tutur iaitu lakuan tutur komisif dan lakuan tutur direktif.

Jadual 1: Kerapan dan peratusan jenis-jenis lakuan tutur dalam tajuk berita akhbar dalam talian

\begin{tabular}{ccc}
\hline Taksonomi Searle & Kekerapan & Peratusan \\
\hline Asertif/Representatif & 52 & 74 \\
Direktif & 9 & 13 \\
ekspresif & 2 & 3 \\
komisif & 6 & 9 \\
Gabungan & 1 & 1 \\
Jumlah & $\mathbf{7 0}$ & $\mathbf{1 0 0}$ \\
\hline
\end{tabular}

Berdasarkan Jadual 1 di atas, lakuan tutur asertif menunjukkan peratusan penggunaan yang paling tinggi. Hal ini jelas memperlihatkan fungsi utama tajuk berita adalah untuk melaporkan atau mendedahkan maklumat semasa bagi sesuatu isu. Lakuan tutur asertif merupakan jenis lakuan bahasa yang mengikat penutur kepada kebenaran proposisi yang diungkapkan dan lakuan ini membawa nilai benar terhadap ungkapan tersebut. Lakuan ini juga mengungkapkan kepercayaan penutur dan mengakibatkan penutur bertanggungjawab terhadap kebenaran ujaran yang dilafazkan. Antara fungsi asertif antaranya ialah menyatakan, mendapatkan maklumat, menafikan, menyarankan, melaporkan dan mengandaikan. Berikut merupakan contoh tajuk-tajuk berita yang disampaikan dalam bentuk lakuan asertif.

1. Isu boikot minyak sawit bukan penghalang M'sia bersuara isu sejagat' (Malaysiakini.com, 30 Oktober 2019, 6:31 PM).

2. Tak berasas kaitkan sawit dengan kemusnahan hutan' (Malaysiakini.com, 23 Ogos 2019, 11:58 AM).

3. Malaysia serah surat bantahan kepada 27 negara EU (bHarian.online.com.my, 21 Januari 2018, 5:14 PM).

4. Koronavirus hanya jejas harga sawit sementara (hmetro.com.my, Selasa, 4 Februari 2020, 8:09 PM). 
Menurut Searle (1979) dalam asertif, penutur komited terhadap sesuatu yang berlaku. Tajuk berita yang disampaikan dalam bentuk lakuan tutur asertif mempunyai tindakan illokusi untuk melaporkan dan mendedahkan pembaca tentang isu minyak sawit yang berlaku dan juga 'menafikan' beberapa fakta tentang minyak sawit yang dilaporkan dalam akhbar luar negara. Asertif adalah ujaran yang bertujuan untuk memberitahu pendengar bagaimana keadaan dalam dunia. Dengan perkataan lain, asertif adalah gambaran tentang realiti. Lakuan ini juga adalah lakuan tutur yang mempertanggungjawabkan penutur kepada kebenaran suatu proposisi. Asertif merujuk kepada pernyataan, keterangan, klasifikasi, penerangan, dan penjelasan. Sebilangan besar asertif digunakan dalam tajuk berita akhbar dalam talian sama ada tanpa kata kerja (Tajuk 1, dan 4) atau dengan kata kerja (Tajuk 3 iaitu kata kerja 'serah') memaklumkan kepada pembaca apa yang berlaku dan mendedahkan beberapa fakta dalam tajuk-tajuk berita. Penyampaian tajuk berita dalam bentuk lakuan asertif boleh dikaitkan dengan fakta bahawa fungsi tajuk berita adalah untuk melaporkan atau mendedahkan keadaan semasa. Asertif menangani topik yang berbeza dalam tajuk berita tentang isu sawit. Antaranya membidas kritikan luar negara terhadap industri sawit dan mempertahankan industri sawit.

Lakuan direktif digunakan untuk membuatkan pendengar melakukan sesuatu. Kelas ini termasuklah lakuan menasihat, meminta, mengarah, melarang, mencadangkan, mendesak, mengesyorkan dan sebagainya. Dalam kajian ini, sebanyak 9 tajuk berita yang menggunakan lakuan direktif ditemui dalam sample kajian yang antaranya adalah seperti berikut.

5. Lepas bertukar kerajaan, MCA gesa India beli semula minyak sawit (Malaysiakini.com, 1 Mar 2020, 4:20 PM).

6. Agensi sawit desak_kerajaan henti runding sawit dengan EU - (bHarian.online.com.my, 6 Mac 2019, 7:01 PM).

7. 'Haramkan mentega dari EU' (bHarian.online.com.my, 28 Januari 2018, 6:57 PM).

Penggunaan kata kerja gesa, desak dan haramkan menunjukkan sesuatu cubaan penutur/penulis untuk mendapatkan pendengar melakukan sesuatu tindakan yang dihajatkan iaitu memerlukan seseorang itu bertindak atas permintaan yang dikehendaki. Lakuan direktif dalam tajuk berita (5- 7) membawa fungsi mendesak dan mengarah. Perkataan gesa dalam (5) bermaksud menyuruh dengan bersungguh-sungguh dan mendesak (Kamus Dewan Online, t.th.), manakala maksud perkataan haram adalah melarang dan menegah. Akhiran-kan yang hadir bersama kata kerja haram menjadikan ayat itu sebagai ayat suruhan yang bermaksud kausatif atau menyebabkan jadi iaitu dalam konteks tajuk berita (7), bermaksud menyebabkan jadi haram. Maksud kedua-dua perkataan gesa dan haram merujuk ungkapan direktif yang berupa arahan kepada seseorang atau sekumpulan orang untuk membuatkan pendengar melakukan sesuatu. Kuasa ujaran direktif menghasilkan kesan tertentu yang dapat dilihat melalui tindakan dan respons yang ditunjukkan oleh pendengar. Kesan tersebut mungkin berbentuk satu paksaan dan tegahan yang mesti dipatuhi oleh pendengar atau sebagai pengajaran sahaja oleh pendengar. Manakala dalam tajuk berita (6), perkataan desak bermaksud menyuruh (menuntut, meminta) dengan bersungguh-sungguh. Fungsi direktif, mendesak dan melarang adalah lebih keras yang menghendaki sesuatu kehendak atau permintaan itu dilakukan atau dipenuhi oleh pihak yang lagi satu. Dalam kajian ini, penggunaan direktif adalah lebih mengarah kepada isu protes dan serangan kepada pihak 
yang melakukan eksplotasi dan kritikan kepada permintaan sawit dengan tajuk berita menggunakan gesa, desak dan haram sebagai pilihan perkataan.

Komisif yang menunjukkan $9 \%$ merupakan jenis lakuan tutur yang mengikat penutur kepada sesuatu tindakan pada masa akan datang. Perlakuan ini melahirkan niat penutur untuk melakukan sesuatu pada masa hadapan. Lakuan ini menyebabkan penutur melakukan sesuatu tindakan dan perbuatan yang diniatkan. Dalam tajuk-tajuk berita tentang industri sawit, lakuan komisif memperlihatkan jangkaan dan kemahuan tentang sesuatu pada masa hadapan iaitu menyatakan tindakan yang akan dilakukan dalam menghadapi isu memboikot penggunaan produk minyak sawit.

8. Isu minyak sawit: Malaysia akan bertindak balas - PM (bHarian.online.com.my, 19 Mac 2019, 8:23 PM).

9. Malaysia mahu tubuh Jawatankuasa Khas Ekonomi Teknikal Sawit (bHarian.online.com.my, 23 November 2017, 4:34 PM).

10. Akhbar: Subsidi minyak masak dijangka dipotong, harga_bakal_naik (Malaysiakini.com, 19 Oct 2016, 6:01 PM).

Tajuk berita (8), (9) dan (10) di atas, mengandungi maksud sesuatu lakuan atau tindakan bakal berlaku atau dilakukan pada masa hadapan. Dalam tajuk berita (8), kata kerja bantu_akan bermaksud Malaysia (berhajat) untuk bertindak balas (terhadap sesuatu) pada masa hadapan/akan datang. Tajuk berita (9), kata kerja mahu bersinonim dengan hendak, berhasrat dan berhajat (sesuatu) iaitu dalam konteks ini, Malaysia (hendak/ berhasrat/ berhajat) menubuhkan jawatankuasa pada masa hadapan/akan datang dan dalam (10), kata kerja dijangka merujuk sesuatu akan berlaku pada masa hadapan yang mana dalam konteks berita ini, subsidi minyak masak akan dipotong. Malah dalam ayat (10), penggunaan perkataan bakal juga merupakan pelaksanaan lakuan komisif iaitu yang membawa maksud akan_menjadi sesuatu.

Dalam melaksanakan lakuan ini, ada beberapa fungsi komisif yang ditunjukkan dalam tajuk berita iaitu sebagai komitmen pada tindakan masa hadapan (Kempen antiminyak sawit: Malaysia akan fail tindakan undang-undang ke atas EU - 1 Julai 2020, 9:19 PM), sebagai kemungkinan tindakan masa hadapan (Akhbar: Subsidi minyak masak dijangka dipotong, harga bakal naik (Malaysiakini.com, 19 Oct 2016, 6:01 PM), mengumumkan tindakan pada masa hadapan (Malaysia mahu tubuh Jawatankuasa Khas Ekonomi Teknikal Sawit (bHarian.online.com.my, 23 November 2017, 4:34 PM) dan berjanji untuk masa hadapan Malaysia, Indonesia akan cabar peraturan EU di WTO (bharian.online.com.my, 16 Julai 2019, 10:05 PM).

Ekspresif digunakan untuk mengungkapkan perasaan yang berkaitan dengan lakuan atau tindakan tertentu. Lakuan tutur ekspresif mempunyai kekerapan yang paling rendah berbanding lakuan tutur yang lain iaitu hanya $3 \%$ atau 2 kekerapan. Kedua-dua tajuk berita ini dizahirkan sebagai luahan tidak bersetuju atas larangan dan diskriminasi penggunaan minyak sawit sebagaimana ditunjukkan dalam dua data berikut;

11. FELDA bantah keputusan EU boikot minyak sawit (bHarian.online.com.my, 16 Januari 2018, 5:20 PM).

12. Sepanyol turut bantah tindakan diskriminasi minyak sawit (bHarian.online.com.my, 13 Februari 2018, 3:34 PM). 
Kekerapan yang rendah bagi kemunculan lakuan ekspresif mungkin menandakan bahawa tajuk-tajuk berita hanya memberi perhatian yang sedikit terhadap ekspresi perasaan dan juga membayangkan sikap yang neutral bagi sesuatu peristiwa (Al-Hindawi \& Ali, 2018).

Lakuan tutur gabungan adalah adalah tutur yang ditemui menggabungkan dua atau lebih lakuan tutur dalam satu tajuk berita. Hanya satu data bersamaan $1 \%$ sahaja yang ditemui dalam bentuk ini iaitu gabungan antara lakuan tutur komisif (akan) dengan lakuan tutur direktif (minta) sebagaimana tajuk berita berikut:

13. FELCRA akan minta Malaysia haramkan produk EU (bHarian.online.com, 14 Mac 2019, 11.58 PM)

Kata bantu akan ialah lakuan tutur komisif yang memberi maksud sesuatu tindakan yang akan dilakukan iaitu tindakan meminta yang merupakan lakuan tutur diirektif iaitu satu permintaan atau permohonan yang disampaikan secara langsung untuk mendapatkan sesuatu.

Kekerapan lakuan asertif dalam tajuk berita akhbar dalam talian MalaysiaKini.com, bHarian.online.com.my dan hmetro.com.my menonjolkan akhbar dan portal akhbar ini cenderung menyampaikan maklumat tentang industri sawit dalam bentuk pelaporan dan pendedahan untuk menggambarkan situasi yang berlaku. Analisis data juga menunjukkan penggunaan kata kerja performatif eksplisit dan implisit dalam tajuk-tajuk berita dalam tiga akhbar yang dikaji. Jadual 2 menunjukkan penggunaan lakuan tutur perfomatif. Analisis memperlihatkan penulis atau editor bagi tajuk-tajuk berita menggunakan 50 tajuk berita (termasuk bentuk gabungan) dan 70\% lakuan tutur yang muncul dalam bentuk eksplisit. Sebaliknya, penulis atau editor tajuk berita menggunakan hanya 21 kekerapan dan $30 \%$ untuk melaksanakan lakuan tutur secara implisit.

Jadual 2: Tindakan Performatif dalam Tajuk Berita

\begin{tabular}{cc}
\hline Tindakan perfomatif & Peratusan \\
\hline Performatif eksplisit & 70 \\
Performatif implisit & 30 \\
\hline
\end{tabular}

Dalam kajian ini, lakuan tutur asertif yang digunakan dalam akhbar dalam talian adalah lebih kerap disampaikan dalam bentuk perfomatif eksplisit, iaitu 38 kekerapan atau 54\% berbanding lakuan tutur yang lain. Manakala hanya 14 kekerapan atau 20\% tajuk berita disampaikan dalam bentuk performatif implisit. Sebagai contoh, "Isu industri kelapa sawit dapat perhatian YB" dan "EU, Perancis bukan musuh minyak sawit". Kedua-dua tajuk berita ini disampaikan dalam bentuk perfomatif implisit iaitu tidak menggunakan kata kerja performatif untuk menamakan lakuan tersebut (lakuan asertif). Direktif yang berada pada kekerapan kedua penggunaannya dalam tajuk berita juga muncul sebagai lakuan tutur eksplisit dengan 9 kekerapan atau 13\%. Begitu juga lakuan ekspresif yang disampaikan dalam bentuk tindakan performatif eksplisit iaitu sebanyak 2 kekerapan atau 3\%. Walau bagaimanapun, komisif muncul dalam bentuk lakuan tutur yang digunakan secara implisit sahaja. Data menunjukkan 6 kekerapan dengan 9\% lakuan tutur implisit digunakan sebagai komisif. Manakala bentuk gabungan terdiri daripada 1 bentuk eksplisit (minta) dan 1 dalam bentuk implisit (akan). 


\begin{tabular}{ccccc} 
& \multicolumn{5}{c}{ Jadual 3: Tindakan } & \multicolumn{3}{l}{ Performatif eksplisit dan implisit dalam tajuk berita } \\
\hline Taksonomi Searle & eksplisit & Peratusan & Implisit & peratusan \\
\hline Representatif & 38 & 53 & 14 & 20 \\
Direktif & 9 & 13 & & 9 \\
komisif & 2 & 3 & 6 & \\
Ekspresif & 1 & 1 & 1 & 1 \\
Gabungan & $\mathbf{5 0}$ & $\mathbf{7 0}$ & $\mathbf{2 1}$ & $\mathbf{3 0}$ \\
Jumlah & & & & \\
\hline
\end{tabular}

Dalam asertif, penggunaan kata kerja akui (data 13), sokong (data 14) dan bincang (data 15) memperlihatkan kata kerja performatif yang menunjukkan makna performatif disampaikan secara eksplisit sebagai mengakui sesuatu, menyokong sesuatu dan membincangkan sesuatu.

14. 'Pemimpin Perancis akui kempen negatif EU ke atas sawit M'sia tak berasas'(Malaysiakini.com, 20 Mac 2019, 11:10 AM).

15. Industri penerbangan sokong kempen 'Love MY Palm Oil' (bharian.com.my, 22 Januari 2019, 4:53 PM).

16. Malaysia, negara EU bincang isu dua hala khususnya minyak kelapa sawit (Malaysiakini.com, 26 Jan 2019, 1:56 PM).

Kesemua lakuan tutur direktif dalam tajuk berita menggunakan tindakan performatif eksplisit. Penulis menggunakan kata kerja direktif iaitu galakkan, gesa, haramkan, seru, minta dan saran sebagai pilihan kata kerja. Kesemua kata kerja ini dizahirkan secara eksplisit iaitu satu tindakan jelas untuk membuatkan sesuatu pihak lain melakukan sesuatu. Sebagai contoh dalam ayat "Lepas bertukar k'jaan, MCA gesa India beli semula minyak sawit" (MalaysiaKini.com, 1 Mar 2020, 4:20 PM). Kata kerja gesa bermaksud menyuruh dengan sungguh-sungguh atau mendesak. Begitu juga dengan lakuan ekspresif yang disampaikan dalam bentuk performatif eksplisit bagi menzahirkan tindakan secara tidak berselindung. Penggunaan kata kerja bantah dalam ayat "FELDA bantah keputusan EU boikot minyak sawit" (bharian.com.my, 16 Januari 2018, 5.20 PM) menunjukkan penulis cuba menyampaikan maksud bahawa pihak FELDA benar-benar tidak bersetuju dengan keputusan EU iaitu maksud tidak bersetuju disampaikan secara terang-terangan.

Sebaliknya kesemua lakuan komisif disampaikan dalam bentuk perfomatif implisit. Dalam tajuk berita "Sawit: Malaysia, Indonesia akan cabar peraturan EU di WTO" (BHarian.com.my, 16 Julai 2019, 10:05 PM), disampaikan dengan tidak menggunakan kata kerja performatif eksplisit bagi melaksanakan lakuan komisif. Walaupun dalan tajuk berita tersebut tidak menggunakan kata kerja performatif eksplisit komisif seperti berjanji, berazam atau menjamin namun maksud performatif komisif melakukan sesuatu pada masa hadapan masih difahami secara tersirat dengan penggunaan kata bantu aspek akan yang membawa maksud sesuatu lakuan atau tindakan yang belum dilakukan dan akan dilakukan pada masa hadapan. Dalam bentuk eksplisit, tajuk berita tersebut boleh disampaikan dalam bentuk "Sawit: Malaysia, Indonesia berjanji cabar peraturan EU di WTO".

\section{PERBINCANGAN}

Kebanyakan tajuk-tajuk berita dianggap sebagai "bukan-ayat" (Stainton, 2006). Elemen kenahuan dalam tajuk berita distruktur berasaskan kepada apakah item berita yang dianggap sebagai "titik tumpuan". Bagi pembaca, tajuk berita bertindak sebagai "titik masuk" kepada 
berita. Pembaca akan memutuskan sama ada untuk terus membaca keseluruhan berita atau tidak bergantung kepada bagaimana maklumat yang relevan diketengahkan dalam tajuk berita. Oleh itu, tajuk berita telah didefinisikan sebagai "... jenis teks yang unik dengan kepelbagaian fungsi yang menentukan bentuk, kandungan dan strukturnya" (Reah, 1998, yang dipetik dalam Al-Saedi dan Jabber (2020)).

Dapatan kajian ini mendedahkan bahawa tajuk-tajuk berita yang dipilih menunjukkan tindakan illokusi (maksud) tertentu yang hendak disampaikan kepada pembaca. Dalam konteks pelaporan berita dalam akhbar, penulis melaporkan berita yang diperoleh daripada suatu pihak tertentu. Dalam tajuk berita berbentuk asertif, terkandung maksud penutur yang percaya akan situasi yang dinyatakan. Dalam lakuan direktif pula, penutur berkehendakkan sesuatu situasi. Tajuk berita yang disampaikan dalam bentuk lakuan komisif menzahirkan niat penutur bagi sesuatu situasi. Manakala lakuan ekspresif pula menyatakan perasaan penutur terhadap sesuatu situasi yang berlaku.

Tujuan menggunakan peratusan tertinggi asertif di sebalik tindakan ini adalah untuk memberitahu pembaca mengenai situasi yang berkaitan dengan industri sawit. Tajuk berita mengandungi maklumat yang penting dan relevan bagi sesuatu laporan berita. Dengan demikian, maklumat penting dari sebuah berita perlu disajikan dengan cara yang menarik yang boleh menangkap perhatian pembaca. Tajuk berita dapat dikenali dengan mudah dan menurut Moncomble (2016), setelah berkembang selama lebih dari dua abad, tajuk berita (sejak awal abad ke-20) mencapai bentuk tetap yang sangat homogen di seluruh akhbar berbahasa Inggeris dan dunia berbahasa Inggeris. Moncomble (2016) ada menggariskan ciriciri untuk menulis tajuk berita yang baik. Dari segi kandungan tajuk berita antaranya ringkas, jelas, senang difahami, tidak kabur, menarik, mengandungi maklumat baru dan jangan mengandaikan maklumat yang tidak diketahui oleh pembaca. Dari segi struktur tajuk berita pula, antaranya, elak penafian, tidak menggunakan kata nama sebagai adjektif, tidak menggunakan kata adjektif jamak dan mengguna kala kini. Kajian ini mencadangkan bahawa lakuan tutur juga boleh merupakan sebahagian ciri bagi penulisan tajuk berita.

Dalam konteks kajian Al-Saedi dan Jabber (2020) yang mengkaji aspek pragmatik dalam tajuk berita surat khabar rasmi Iraq (Alsabah Newspaper) dengan tumpuan kepada peristiwa yang berlaku di Iraq mendapati lakuan tutur ekspresif dan deklaratif adalah lakuan tutur yang paling menonjol digunakan dalam sampel tajuk berita. Penggunaan lakuan tutur ini dalam tajuk berita akhbar Alsabah menggambarkan perasaan pembaca untuk menzahirkan perasaan kejayaan dan pembebasan. Berdasarkan perbandingan dapatan Al-Saedi dan Jabber (2020) dengan kajian ini yang menunjukkan penyerlahan lakuan tutur representatif /asertif berbanding lakuan tutur yang lain dalam penulisan tajuk berita tentang isu sawit, dapat dijelaskan bahawa tajuk berita juga dipengaruhi oleh isu dan penekanan berita yang hendak dilaporkan oleh penulis.

Dalam situasi mengekspresikan perasaan kegembiraan atas kejayaan pembebasan daripada peperangan, lakuan ekspresif dan deklaratif lebih sesuai diungkapkan pada ketika itu yang bukan sahaja pelaporan tetapi juga berkongsikan kegembiraan tersebut secara bersama dengan khalayak dan juga mengistiharkan sesuatu perubahan status iaitu untuk menyatakan pencapaian kemenangan dan pembebasan. Namun isu mengenai industri sawit atau lebih tepat lagi kempen anti-minyak sawit yang menimpa industri sawit Malaysia adalah berbeza. Dalam pemaparan isu sawit, kebanyakan akhbar dan portal berita dalam talian hanya cenderung memberitahu dan melaporkan isu ini kepada pembaca. Hal ini kerana isu tentang industri sawit hanya relevan kepada pihak-pihak berkepentingan tertentu sahaja 
yakni tidak melibatkan sebahagian besar masyarakat awam. Malah ada khalayak yang tidak tahu atau tidak mengendahkan pun isu mengenai industri sawit yang menimpa Malaysia. Justeru analisis ini menganggap kekerapan lakuan asertif yang dipersembahkan sebagai tajuk berita tentang sawit/industri sawit adalah hanya berfungsi sebagai 'mendedahkan', 'melaporkan', 'menafikan' dan 'mempertahankan' sesuatu maklumat tentang industri sawit kepada pembaca atau khalayak. Lakuan ini selaras dengan maksud berita iaitu satu bentuk pelaporan yang memberikan informasi mengenai sesuatu peristiwa benar dan semasa kepada masyarakat (Shahrul Nazmi \& Ong, 2016). Kekerapan yang tinggi penggunaan lakuan tutur asertif ini juga selaras dengan fakta yang fungsi teras tajuk berita adalah untuk melaporkan atau mendedahkan keadaan semasa bagi sesuatu isu tertentu (Qomariyah, 2019). Dalam penyampaian tajuk berita, pembaca tidak perlu diarah (lakuan direktif) atau dijanjikan (komisif) atau meluahkan sikap psikologi (ekspresi) sesuatu dalam penyampaian berita. Malah perkataan yang membawa maksud arahan belum pasti akan dilaksanakan arahan yang diberi. Sebagai contoh dalam tajuk berita, 'Kerajaan digesa tangani cadangan EU larang minyak sawit' (MalaysiaKini, 16 Mar 2019, 10:14 PM). Sungguhpun lakuan tutur direktif 'gesa' dilaksanakan namun tajuk berita ini adalah hanya pelaporan daripada berita yang menyebut Felda, Felcra, Risda dan Persatuan Kebangsaan Pekebun-Pekebun Kecil Malaysia menggesa kerajaan menghentikan semua rundingan dagang dengan kerajaan Eropah sementara menunggu resolusi cadangan Kesatuan Eropah (EU) untuk melarang penggunaan minyak sawit sebagai bahan bakar bio menjelang 2020.

Pembaca hanya perlu mengetahui, menerima dan mempercayai maklumat berita yang memberikan impak signifikan kepada pembaca. Dari segi kesan kognitif juga lebih rendah untuk memproses maklumat berbanding untuk memikir sesuatu arahan, lakuan masa hadapan dan menilai sikap psikologi penulis. Menurut Dor (2003, dalam Vandana et al., 2019), tajuk utama adalah "perunding antara cerita dan pembaca, "dan mempunyai berbagaibagai fungsi, iaitu, untuk memilih dan menyerlahkan butiran utama berita. Berdasarkan fungsi, Gattani (2007, dipetik dalam Vandana et al. (2019)) mengenal pasti tajuk berita sebagai (a) informative, (b) indikatif, atau (c) persuasif. Ismail (2016) menerangkan fungsi utama tajuk utama untuk memaklumkan kepada pembaca secara ringkas mengenai teks iaitu artikel berita. Beliau selanjutnya menambah bahawa melalui "gaya publisiti" tajuk berita mempengaruhi dan meyakinkan pembaca mengenai perkara yang dinyatakan dalam rencana. Dua fungsi utama tajuk berita ialah (a) mengindeks berita, dan (b) menarik pembaca. Oleh itu, tajuk utama mempunyai ciri-ciri sebagai bermaklumat dan juga persuasif. Tajuk berita yang bermaklumat adalah yang memberikan maklumat "baru" mengenai perkara / peristiwa "lama" atau "diketahui", sedangkan tajuk utama persuasif menyajikan maklumat yang "diketahui" baru atau cara menyerang (Vandana et al., 2019).

\section{KESIMPULAN}

Penelitian tajuk-tajuk berita 'sawit' mendedahkan bagaimana tajuk-tajuk berita membuat liputan tentang isu kelapa sawit dalam akhbar dalam talian tempatan dengan menggunakan analisis makna pragmatik untuk menarik perhatian pembaca. Hasil kajian menunjukkan bahawa penulis tajuk berita menggunakan empat klasifikasi lakuan tutur iaitu asertif, direktif, komisif dan ekspresif sebagai cara untuk melaksanakan makna yang dihajatkan dan menyampaikan mesej kepada pembaca mengenai isu industri sawit Malaysia. Daripada empat klasifikasi yang digunakan, didapati lakuan asertif paling kerap digunakan sebagai tajuk berita. Kekerapan ini menyaksikan bahawa berita industri sawit dan isu sawit disampaikan dalam bentuk pelaporan berita atau maklumat kepada pembaca. Kekerapan lakuan asertif 
sebagai tajuk berita juga dapat mengesahkan fakta yang fungsi utama tajuk berita adalah untuk melaporkan dan mendedahkan keadaan semasa bagi isu-isu tertentu.

Industri sawit merupakan nadi ekonomi negara. Pelaporan tajuk akhbar bersifat asertif sebenarnya dapat membantu memahamkan khalayak tentang situasi konflik yang berlaku dalam tempoh sepuluh dekad ini. Serangan demi serangan dari blok Kesatuan Eropah dengan cuba mengheret isu alam sekitar, kepupusan haiwan orang utan, eksploitasi buruh kesemuanya telah dapat dijawab dengan baik oleh Malaysia. Dari segi prinsipnya lakuan komisif, direktif lebih sesuai digunakan di peringkat penyelesaian isu sawit. Tetapi untuk meyakinkan pembaca dan pengguna tentang kepentingan industri ini diperkasakan adalah lebih sesuai jika lakuan asertif dipilih.

Kajian ini secara tidak langsung dapat mengetengahkan cara pihak pengurusan menghadapi krisis konflik sawit di peringkat kebangsaan dan global. Kajian seterusnya boleh dilakukan dengan membandingkan gaya penghasilan tajuk berita akhbar antarabangsa berkaitan sawit yang mungkin boleh memberi petunjuk kepada kita sama ada isu alam sekitar, kepupusan orang utan dan eksploitasi lebih kepada niat sebenar atau lebih kepada strategi menghadapi saingan sawit di peringkat global.

\section{PENGHARGAAN}

Atikel ini adalah berasaskan kepada penyelidikan ZF2019-006 yang bertajuk 'Wacana Kelapa Sawit dalam Media: Analisis Teks dan Imej'.

\section{BIODATA}

Maslida Yusof ialah Profesor Madya di Pusat Kajian Bahasa, Kesusasteraan dan Kebudayaan Melayu, UKM. Bidang pengkhususan beliau ialah semantik dan pragmatik. E-mel: maslida@ukm.edu.my

Nor Hashimah Jalaluddin ialah Profesor di Program Linguistik. Beliau banyak menjalankan penyelidikan mengenai Akal Budi Melayu, Geolinguistik dan Tatabahasa Bahasa Melayu. Beliau telah banyak menghasilkan buku dan artikel jurnal hasil daripada penyelidikannya. Beliau juga banyak menyelia pelajar pascasiswazah juga berkisar tentang penyelidikan yang dijalankan. E-mel: shima@ukm.edu.my

Harishon Radzi ialah pensyarah kanan di Program Linguistik, Pusat Kajian Bahasa dan Linguistik, Universiti Kebangsaan Malaysia. Bidang kepakaran beliau ialah morfologi, linguistik dan komunikasi serta geolinguistik. E-mel: naslin@ukm.edu.my

Karim Harun ialah Profesor Madya di Pusat Pengajian Bahasa, Kesusasteraan dan Kebudayaan Melayu, UKM. Bidang pengkhususan beliau ialah leksikografi dan psikolinguistik. E-mel: linguist@ukm.edu.my 


\section{RUJUKAN}

Abd. Rasyid, \& Haidir Fitra Siagian. (2017). News value and reality: A case study. Jurnal Komunikasi: Malaysian Journal of Communication, 33(3), 55-69.

Al-Hindawi, F. H. \& Ali, A. H. (2018). A pragmatic study of CNN and BBC news headlines covering the Syrian conflict. Advances in Language and Literary Studies, 9(3), 43-51.

Al-Saedi, H. T. J. \& Jabber, K. W. (2020). A pragmatic study of newspaper headlines in media discourse: Iraq as a case study. International Journal of Linguistics, Literature and Translation (IJLLT), 3(3), 48-59. https://al-kindipublisher.com/index.php/ijllt/

Aszlan Selamat, \& Shakila Yacob. (2019). Isu antiminyak sawit dan peranan surat khabar dalam mencorakkan hubungan Malaysia-Amerika Syarikat, 1986-1989 (Anti-Palm Oil Issue and the Role of U.S. Newspapers in Shaping Malaysia-US relations, 1986-1989). Jebat: Malaysian Journal of History, Politics \& Strategic Studies, 46(2), 295-321.

Austin, J. (1962). How to do things with words. Oxford University Press.

Azahar Kasim, \& Adibah Ismail (2018). Framing strategic news from the perspective of media organizations in Malaysia. Jurnal Komunikasi: Malaysian Journal of Communication, 34(1), 330-344.

Azlizan Mat Enh, \& Norlilawati Samak. (2020). Peranan akhbar sebagai wadah komunikasi pemerintah selepas pilihan raya umum 1969. Jurnal Komunikasi: Malaysian Journal of Communication, 36(1), 1-19.

Beard, A. (2000). The language of politics. Routledge.

Bell, A. (1991). The language of news media. Blackwell.

Chiluwa, I. (2007). News headlines as a pragmatic strategy in Nigerian Press discourse. The International Journal of Language Society and Culture, 27, 63-71.

Corciolani, M., Gistri, G., \& Pace, S. (2017). Mega marketing and sustainability in contested markets: A longitudinal analysis of media discourses about palm oil. Contributor in Atti di Convegno (Proceeding). http://hdl.handle.net/11568/875665

Ehineni, T. O. (2014). A syntactic analysis of lexical and functional heads in Nigerian English newspaper headlines. International Journal of Linguistics, 6(5), 9-21. http://dx.doi.org/10.5296/ijl.v6i5.6110

Ismail, H. M. (2016). The pragmatic and semantic potential of newspaper headlines. US-China Foreign Language, 14(11), 753-762.

Kamus Dewan Online. (t.th.) Kamus Bahasa Melayu: Minta. Dewan Bahasa dan Pustaka. https://prpm.dbp.gov.my/Cari1?keyword=minta\&d=176312\&\#LIHATSINI.

Lee Kuok Tiung, Aisah Meri, Liana Mat Nayan, \& Siti Suriani Othman. (2016). Kegunaan dan kepuasan portal berita dalam kalangan belia Malaysia. Jurnal Komunikasi: Malaysian Journal of Communication, 32(2), 790-816.

Leetaru, K., \& Thoumi, G. (2017, Nov 6) The palm oil industry: Visualized through big data. CFA Institute. https://blogs.cfainstitute.org/investor/2017/11/06/

Mohd Hazreen Shah Hassan, \& Sharil Nizam Sha'ri. (2019). Analisis kesalahan penggunaan bahasa dalam rencana akhbar. Jurnal Pengajian Media Malaysia, 21(2), 55-71.

Mohd Hazreen Shah Hassan, Sharil Nizam Sha'ri, \& Nor Azuwan Yaakob. (2019). Keberkesanan penggunaan bahasa dalam akhbar Melayu: Tindak balas strategik terhadap literasi kesihatan dalam kalangan pembaca tempatan. Jurnal Sultan Alauddin Sulaiman Shah, 6(1), 95-109. 
Moncomble, F. (2018). The deviant syntax of headlinese and its role in the pragmatics of headlines. E-rea, 15.2. https://doi.org/10.4000/erea.6124

Monsefi, R., \& Mahadi, T. S. T. (2017). The rhetoric of Persian news headlines: A case study of Euronews. International Journal of Applied Linguistics and English Literature, 6(2), 36-45. http://dx.doi.org/10.7575/aiac.ijalel.v.6n.2p.36

Muhammad Nur Ruhaizad. (2015). Kesan perubahan permintaan minyak sawit di Malaysia terhadap perubahan harga minyak sayuran lain (conference paper). Conference Proceedings of Social Sciences Postgraduate International Seminar (SSPIS). School of Social Sciences, Pulau Pinang, Malaysia (pp. 356-364). http://eprints.usm.my/37616/

Murphy, D. J. (2014). The future of palm oil as a major global crop: Opportunities and challenges. Journal of Oil Palm Research, 26(1), 1-24.

Norhuda Salleh. (2016). Tinjauan awal teori tanggungjawab sosial akhbar dalam analisis tajuk utama muka depan Berita Harian 2013. Jurnal Komunikasi Borneo, 4(Edisi Khas Konvokesyen ke-18 UMS), 33-43. http://www.myjurnal.my/public/

Nur Nadia Kamil, Meilina Ong-Abdullah, Ahmad Tarmizi Hashim, Zamzuri Ishak, Balu Nambiappan, \& Azman Ismail. (2020). Economic feasibility of clonal oil palm planting material. Journal of Oil Palm Research, 32(3), 509-517.

Oosterveer, P. (2020). Sustainability of palm oil and its acceptance in the EU. Journal of Oil PALm Research, 32(3), 365-376.

Osama Kanaker, Mohamed Oklah Abughazlih, \& Mohd Faizal Kasmani. (2020). Media framing of minorities' crisis: A study on Aljazeera and BBC News coverage of the Rohingya. Jurnal Komunikasi: Malaysian Journal of Communication, 36(2), 1-16. https://doi.org/10.17576/JKMJC-2020-3602-01

Qomariyah, A. N. (2019). A pragmatic study of Jakarta Post and Jakarta Globe new headlines after Indonesian general election 2019. International Journal of Humanities, Arts and Social Sciences, 5(4), 128-137. https://doi.org/f2mp

Rabiah Rustam, Akbar Ali Muhammad, \& Imran. (2019). Identification and analysis of commissive speech act to decode indirect messages in news headlines. Global Social Sciences Review (GSSR), IV(I), 327-334.

Rosman Al-Qadri. (2019). Senarai top 10 Berita / Newspaper online di Malaysia 2019. Bomstart: Digital Marketing Agency. https://bomstart.my/top-10-berita-

Searle, J. R. (1969). Speech acts An essay in the philosophy of language. Cambridge University Press.

Searle, J. R. (1979). A taxonomy of illocutionary acts. In Searle J. R. (Ed.), Expression and Meaning: Studies in the theory of speech acts (pp. 1-29). Cambridge University Press.

Shahrul Nazmi Sannusi, \& Normah Mustaffa. (2015). Akhbar versi digital: Implikasi terhadap trend sirkulasi akhbar bercetak di Malaysia. Jurnal Komunikasi: Malaysian Journal of Communication, 31(2), 687-701.

Shahrul Nazmi Sannusi, \& Ong Yi Min. (2016). Strategi pemilihan berita halaman hadapan akhbar berbahasa Melayu dan Cina: Kajian terhadap Berita Harian dan China Press. Jurnal Melayu, 15(1), 14-25.

Stainton, R. J. (2006). The pragmatics of non-sentences. In L. R. Horn \& G. Ward (Eds.), The handbook of pragmatics (pp. 266-287). Blackwell Publication.

Taiwo, R. (2007). Language, ideology and power relations in Nigerian newspaper headlines. Nebula, 4(1), 218- 245. 
The Birth Site. (2020, Feb 22). Berita dalam talian vs akbar. https://ms.thebirthsite.com/post/

Usahawan.com. (t.th.) Industri Sawit di Malaysia. https://www.usahawan.com/sawit

Vandana, Chakraborty, J., \& Dash, N. S. (2019). Analyzing structures of Hindi newspaper headlines: A discourse perspective. Journal of Advanced Linguistic Studies, 8(1-2), 196-216. 